\title{
Ekko over atlanten
}

\section{Frankofone litteraturer som udfordring til litte- raturhistorien}

Opkomsten af begreber som frankofoni, lusofoni, commonwealth og hispanidad har det seneste halve århundrede skærpet erkendelsen af, at litteratur skrevet på europæiske sprog ikke er geografisk begrænset til Europa. Dermed har de - sammen med de litteraturteoretiske landvindinger bidraget til opbruddet fra det nationalfilologisk inspirerede paradigme, der siden det 19. århundrede har ligget til grund for de fleste fremmedsprogsfags organisatoriske struktur og arbejde med de litterære udtryksformer.

Litteraturhistorien er en af de discipliner, der mest grundlæggende er blevet anfægtet af kritikken af nationalfilologien og udgør derfor et privilegeret sted for en konfrontation mellem gamle og nye teoridannelser og metoder. I arbejdet med de litterære tekster udforskes sammenhængen mellem begreber som historie, litteratur, identitet og sprog fra alle vinkler, og det tidligere lidt ildesete kontekstbegreb står højt på disciplinens dagsorden.

Nærværende artikel, der fokuserer på fransksprogede forhold, beskæftiger sig med nogle metodiske implikationer af overgangen fra en snæver fokusering på fransk litteratur til et kraftigt udvidet genstandsfelt, der med et ikke ganske afklaret begreb kaldes litterær(e) frankofoni(er). Begrebet dækker over en særdeles heterogen virkelighed, og som det ofte er blevet anført, giver det ikke umiddelbart mening at anvende de samme litteraturhistoriske kategorier i arbejdet med en caribisk forfatter, der blander mundtlige fortælletraditioner med en vestlig litterær tradition, en algerisk forfatter, der kæmper imod et kolonialt betinget kulturelt herredømme, men på fjendens sprog søger at videreføre en litterær arabisk tradition, og så den belgiske eller schweiziske forfatter, der i flere henseender indskriver sig i den franske litteraturhistorie. Et helt grundlæggende spørgsmål i arbejdet med de frankofone litteraturer bliver derfor, om der gives en overordnet teoretisk ramme, der adækvat kan anvendes på tekster fra så politisk, kulturelt og sprogligt forskellige områder som Belgien, Canada, Antillerne og Afrika. 
Dette overordnede spørgsmål vil her blive belyst med inddragelse af tekster fra Belgien og fra det fransktalende Canada, Québec. Efter en kort introduktion til frankofonibegrebets historiske forudsætninger og ideologiske implikationer opridses nogle aktuelle udviklingstendenser inden for de frankofone litterære studier. Disse afsnit udgør præludiet til en eksemplificerende analyse af to romaner i et perspektiv, der kan betegnes som institutionelt.

\section{Frankofoni-begrebet kort fortalt}

Frankofoni-begrebet lanceres i 1880 'erne af den franske geograf Onésime Reclus (1837-1916), som anvender termen til at betegne fransktalende sprogsamfund verden over. Efterfølgende optræder begrebet kun sporadisk, indtil det i 1960'erne genoptages af politikere fra de tidligere kolonier i et første forsøg på at formalisere et kulturelt samarbejde mellem Frankrig og de nu selvstændige fransktalende lande.

Op igennem 1960'erne og 1970'erne struktureres et sådant samarbejde og får sideløbende med indførelsen af regeringskonferencer og topmøder for frankofone statsoverhoveder en tydelig politisk dimension. Det bliver i 1998 til Organisation Internationale de la Francophonie, hvis medlemmer - som det meget demokratisk formuleres i organisationens charter - er fælles om at anvende det franske sprog, og som en afsværgelse af, at Frankofonien skulle dække over en form for fransk kulturel 'neo-imperialisme', understreger slutdokumenterne fra de frankofone topmøder gang på gang, at det åbne møde mellem sprog og kulturer er centralt placeret i det frankofone projekt.

Ikke desto mindre kan man i de efterhånden ganske talrige antologier og litteraturhistorier om frankofone litteraturer notere en vis glidning i frankofoni-termens betydningsmæssige indhold. ${ }^{1}$ Til den leksikalske definition af frankofon som fransktalende kan i praksis tilføjes et - uden for Frankrig. Så i klar modstrid med de officielle diskurser iagttages en fortsat skelnen mellem Frankrig og frankofonien, der - bevidst eller ubevidst - tildeler Frankrig en central plads som primus inter pares og således cementerer snarere end udvisker en forskel. Politiske grænser og den historie, de er vidnes-

1. Se for eksempel Lis Novak: „La Francophonie - endnu et imaginært fællesskab?«, in Katrin Hjort (red.): Diskurs - Analyser af tekst og kontekst, København 1998. Forfatteren anskueliggør i en detaljeret analyse af artiklen "Francophonie« fra Grand Dictionnaire encyclopédique Larousse (1982), hvorledes frankofonien fremstilles som et atemporelt, apolitisk og kontekstuafhængigt fænomen samtidig med, at spændingsforhold mellem fransk og lokale sprog - og dermed mellem Frankrig og dets tidligere kolonier - maskeres. 
byrd om, er altså ikke ganske uvæsentlige, når man taler om frankofon(e) litteratur(er).

Det frankofone fællesskab hviler som nævnt først og fremmest på brugen af det franske sprog, hvis udvikling er tæt forbundet med den centralisme, som har kendetegnet såvel fransk politisk kultur som hele det franske åndsliv siden 1600-tallet. I løbet af 1700-tallet er forestillingen om fransk som et særligt klart og rationelt sprog - ganske i tråd med den franske forfatter Antoine de Rivarols (1753-1801) berømte postulat om det franske sprogs universalitet - blevet fælles europæisk tankegods. I denne udvikling finder vi kimen til såvel den ekstremt normbevidste tradition, som i århundreder har domineret kulturmiljøer og undervisningsinstitutioner både i og uden for Frankrig, som til de nærmest mytiske forestillinger om det franske sprogs universalistiske potentiale, der indtil for få årtier siden cirkulerede som et urørligt dogme blandt franskskrivende forfattere.

Et eksempel blandt mange andre er Léopold S. Senghors bidrag til tidsskriftet Esprit's temanummer om det franske sprog fra 1962. I artiklen, som i øvrigt markerer relanceringen af frankofoni-begrebet, hylder den senegalesiske forfatter i lyriske vendinger det franske sprogs rigdom og poetiske egenskaber og slutter med en næsten paradoksal lovprisning af dette vidunderlige redskab, der udsprunget af koloniregimets ruiner kan væve hele verden sammen i humanismens navn. ${ }^{2}$

Ikke blot sprogligt men også litterært har Frankrig længe fremstået som den naturlige model for de øvrige franskskrivende områder. Historisk hænger dette forhold sammen med etableringen af en europæisk litteraturhistoriografi, der op igennem det 19. århundrede konsoliderede sig på den romantiske præmis om sammenfaldet mellem sprog, nation og litteratur. I denne tradition fremhævedes litteraturen som stedet, hvor nationens ånd og særpræg udkrystalliserede sig i nationens sprog. Hermed blev det vanskeligt at argumentere for eksistensen af fransksprogede national-litteraturer uden for Frankrig.

Manglen på et dækkende begreb for de fransksprogede litteraturer uden for Frankrig illustreres glimrende af de mange betegnelser, som i tidens løb er blevet anvendt ikke kun af franske men også af europæiske, nordamerikanske, caribiske og afrikanske litteraturhistorikere: littératures connnexes, périphériques, exotiques, secondaires, marginales eller mineures. Hvor nogle synes topografisk betinget, er andre ikke fri for at konnotere æstetiske værdidomme og afslører, at den universalistisk - men ikke desto mindre stærkt hierarkisk - funderede betragtningsmåde i vidt omfang er blevet overtaget og inkorporeret af de fransksprogede litterære institutioner uden

2. Léopold S. Senghor: »Le français, langue de culture», in Esprit 11 (1962). 
for Frankrig. Begrebsparret centrum/periferi - som fra nogle sider anses for at være forældet og uden interesse - er derfor stadig højst relevant for at begribe den logik, der er på spil i de frankofone litteraturers historie.

Den fransksprogede forfatters udgangssituation kan herefter beskrives som et valg mellem at være universel eller regional, global eller lokal, inden for eller uden for centrum. Dette evige dilemma forklarer i vidt omfang de frankofone forfatteres stærkt ambivalente forhold til Frankrig, der - for dem der stræber efter mere end blot lokal anerkendelse - kan ses som en stadig pendulbevægelse mellem en assimileringsstrategi, hvor forfatteren betingelsesløst underkaster sig de franske sproglige og litterære normer, og en differentieringsstrategi, som indebærer en mobilisering af tematiske og sproglige elementer, der set fra Paris vidner om en synlig andethed.

Den aktuelle skelnen mellem frankofon og fransk litteratur viser med al ønskelig tydelighed, at ideen om litterær frankofoni ikke på nuværende tidspunkt grundlæggende har ændret styrkeforholdet mellem centrum og "periferierne'. Men begrebets opkomst har med problematiseringen af forholdet sat spørgsmålstegn ved centrets normative status og tilført en betydelig dynamik ikke blot til en række litterære bevægelser men også til løsrivelsen fra det nationalfilologiske paradigme. Og dermed til en nytænkning af det teoretiske fundament for tilgangen til de fransksprogede tekster.

\section{Frankofoni-begrebet i de litterære studier}

De frankofone litterœe studier kan næppe prætendere at udgøre en særlig disciplin med egen forskningspraksis og teoretisk kanon, men en lang række aktuelle udgivelser tyder dog på, at genstandsfeltet nærmer sig en vis institutionel legitimitet. ${ }^{3}$ Fælles for de tilgange, der mødes - og strides - på feltet, er deres syn på den litterære tekst som et komplekst mødested for problemstillinger af social, politisk, sproglig, historisk og kunstnerisk karakter. Deler de en ambition om at forene interne og eksterne tilgange til det litterære værk, er der imidlertid divergerende meninger om, hvad denne kontekst egentlig består af, og hvilke determineringer den kan tillægges.

Med henvisning til deres forskningsgenererende potentiale er særlig tre aktuelle udviklingstendenser interessante: den sprogligt orienterede, den postkoloniale og den institutionelle, som kompletterer snarere end udelukker hinanden.

3. Senest Lieven D’hulst et.al (ed).: Les Études littéraires francophones : état des lieux, Lille 2003. 
Den sprogligt orienterede retning fokuserer på de litterære strategier, der problematiserer anvendelsen af det franske sprog. Lise Gauvin hævder med sit begreb om sproglig overbevidsthed [surconscience], at de fransksprogede forfattere uden for Frankrig, som alle er konfronteret med en flersproglig virkelighed, deler en følelse af fremmedhed i sproget. ${ }^{4}$ Denne sproglige 'uro' kan håndteres på forskellig vis, men vil ofte manifestere sig som en af to ekstremer: enten hyperkorrektion eller barok skrivestil. Andre, som f.eks. Rainier Grutman, har med begrebet hétérolinguisme udforsket, hvordan den konkrete tekstliggørelse af sprogmødets aspekter virker i den narrative konstruktion 5 . Man kan indvende, at sådanne sproglige strategier ikke begrænser sig til de frankofone litteraturer, eller som Lise Gauvin replicere, at den franske sprog- og kulturpolitiks ekstremt normative karakter har frembragt en unik situation og herefter lade diskussionen stå åben.

Med en grundlæggende fordring på kontekstualisering af de litterære tekster fremviser den postkoloniale og den institutionelle retning ganske mange metodologiske berøringspunkter. Der ligger dog en væsentlig forskel i deres udgangspunkt, som den institutionelle litteraturhistorie definerer med afsæt i forhold af litterær art, hvorimod den postkoloniale tilgang definerer genstandsområdet ud fra et historisk-politisk vilkår. Det gør ikke den ene tilgang mere anvendelig end den anden, men skaber forskellige muligheder og begrænsninger for de læsninger, der praktiseres i de givne rammer.

Siden Jean-Paul Sartre i 1948 skrev sit berømte essay Orphée noir til Senghors antologi med fransksproget litteratur fra Afrika, Antillerne og Madagascar $^{6}$ har disse litteraturer været genstand for kontinuerlig udforskning i Frankrig. Men den anglofone postkoloniale teori har haft svært ved at få fodfæste og mødes fortsat mest med skepsis - i værste fald tavshed - på franske universiteter. ${ }^{7}$ Først i 1999 konfronteres den med et fransksproget korpus af Jean-Marc Moura, ${ }^{8}$ der siden i en lang række artikler har fortsat sin refleksion over teoriens rækkevidde i de frankofone studier.

4. Lise Gauvin: La Fabrique de la langue, Paris 2004.

5. Rainier Grutman: "Effets hétérolingues dans le roman québécois du XIXe siècle«, in Littérature 101 (1996).

6. Léopold S. Senghor: Anthologie de la nouvelle poésie nègre et malgache de langue française, Paris 1948.

7. Det kan der være flere årsager til. Den postkoloniale teoris interdisciplinære forankring kan tænkes at være vanskeligt forenelig med det franske universitets opretholdelse af ret faste disciplinære skel. En anden forklaring hævder, at den fransk-algierske relation er så forskellig fra det øvrige fransksprogede postkoloniale genstandsfelt, at en generaliserende synsmåde bliver umulig, (jfr. J. Bardolph: Études postcoloniales et littérature, Paris 2002), mens belgiske Jan Baetens fremfører, at mange af den postkoloniale teoris fransksprogede referencer (f.eks. Fanon, Foucault, Lacan, Derrida...) fungerer anderledes i teorikomplekset end i det franske universitetsmiljø, hvad der kan udgøre en barriere. Se Jan Baetens: »Les 'Études culturelles', encore une exception française« in D'Hulst op.cit., pp. 39-47.

8. Jean-Marc Moura: Littératures francophones et théorie postcoloniale, Paris 1999. 
I Mouras optik sigter studiet af de postkoloniale litteraturer mod at aflede metodologiske principper fra analysen af en diskursiv praksis, der yder modstand mod alle former for kolonisering. En af Mouras pointer er, at størstedelen af verdens befolkning - den koloniserede eller den koloniserende - må siges at leve under et postkolonialt vilkår. Derfor kan Moura udstrække teoriens relevans i de frankofone studier til eksempelvis »en litteratur der overvejende er skrevet af efterkommerne fra de europæiske kolonisatorer [...] som ikke har gennemlevet kolonierfaringen: det fransktalende Canada.$^{9}$

Det forekommer imidlertid problematisk at konstruere et genstandsfelt, der uforbeholdent sidestiller de fransksprogede canadieres erfaringer fra bosættelsesimperialismen med dem, der deles af slaveriets efterkommere og det afrikanske kontinent. ${ }^{10}$ Selv om begrebet littercer frankofoni er opstået i tæt forbindelse med afkoloniseringen, og selv om den postkoloniale teori åbner for væsentlige indsigter i en stor del af de frankofone litteraturer, vil en postkolonial behandling af litteratur fra Québec ramme skævt.

Mouras holdning, som illustrerer et af stridspunkterne i de frankofone litterære studier, synes da også at svækkes af den (engelsksprogede) canadiske forsker Linda Hutcheons stringente argumentation for, at det postkoloniale begreb i litteraturhistorisk henseende altid må opfattes ikke bare epokalt men også som et uomgængeligt traumatisk vilkår:

"In other words, to play upon the Latin root of the word, for literary history the postcolonial is always the propter-colonial: it is "after " (post) but also "because of" (propter) the colonial. Given the defining nature of the historical fact of empire, literary historical definitions of the postcolonial should not be extended to include all kinds of marginality [...]. To read literary [sic] historically in specifically postcolonial terms would mean to look at a nation's literature from the particular point of view of this traumatic imperial legacy; $[\ldots]$ To call a literature and its history postcolonial (as opposed to Pakistani or Kenyan, or even emergent) is precisely to state one's intent to study the political, historical, and aesthetic impact of empire. ${ }^{11}$

9. Jean-Marc Moura: "Sur quelques apports et apories de la théorie postcoloniale pour le domaine francophone«, in Jean Bessière et.al. (ed): Littératures postcoloniales et francophonie : Conférences du séminaire de littérature comparée de l'Université de la Sorbonne nouvelle, Paris 2001, p. 165.

10. Jf. Ingemai Larsens artikel til dette nummer af $K \& K$, der understreger, at vi måske nok alle er postkoloniale individer - men på forskellig vis.

11. Linda Hutcheon: "Rethinking the National Model«, in Linda Hutcheon et al.: Rethinking Literary History, Oxford 2002, pp. 18-19. 
Den fransksprogede litteraturhistorie fra Québec, Belgien og Schweiz har længe befundet sig i en slags metodisk vakuum mellem svindende nationalfilologi og gryende postkolonial teori. Det er da næppe heller tilfældigt, at den institutionelle tilgang har vundet særlig genklang hos forskere fra disse områder. Den institutionelle retning tager sit udgangspunkt i en konstatering af, at der trods irreduktible politiske, historiske og sproglige forskelligheder findes ét fælles grundvilkår for de litteraturer, der skrives på fransk uden for Frankrig: det er den symbolske dominans, der er forbundet med den franske litteraturs status, og som de alle i et eller andet omfang konfronteres med. På dette grundlag hævdes eksistensen af et frankofont litterært system. ${ }^{12}$

Ideen om litteraturen som system er hverken ny eller reserveret til de frankofone studier. Men først de senere år er der med kraftig inspiration fra Pierre Bourdieus feltteori kommet argumenterede bud på et sådant frankofont litterært systems struktur og funktionsmåde. Bourdieu opfatter som bekendt det litterære felt som en relativ autonom sfære, der får sin dynamik fra interessekonflikterne mellem de implicerede parter. ${ }^{13}$ Disse konflikter følger en specifikt litterær logik, idet de udkæmpes med litterære midler og motiveres af alles kamp for at opnå litterær anerkendelse og bestemme, hvad der er legitim litteratur.

Det frankofone system fungerer på lignende vis med den vigtige undtagelse, at de litterære konflikter overvejende er bilaterale, hvilket vil sige, at de fransksprogede litteraturer hver især indgår i en sammenlignelig intrasystemisk relation til Frankrig, men sjældent er i direkte konflikt med hinanden uden centrets mellemkomst i form af litteraturkritik, forlags- eller distributionsvirksomhed. Den belgiske litteraturforsker Marc Quaghebeur har udtrykt manglen på et frankofont alternativ til den bilaterale model så kort og præcist, at det næppe behøver en oversættelse, ça ne circule pas entre nous!

At anskue relationerne mellem Frankrig og de øvrige fransksprogede litteraturer som system har metodiske implikationer på to forskellige niveauer: for det første inddrager denne synsmåde ikke hver enkelt nationalt felt i sin helhed, men ser systemet som den fællesmængde af forfattere, der med deres søgen efter anerkendelse i det parisiske centrum accepterer de her gældende spilleregler; for det andet kiles det frankofone litterære system ind

12. Pierre Halen: "Notes pour une topologie institutionnelle du système littéraire francophone«, in Littérature et Sociétés Africaines. Regards comparatistes et perspectives interculturelles, Tübingen 2001.

13. Pierre Bourdieu: Les Règles de l'art. Genèse et structure du champ littéraire, Paris 1992. Se også Carsten Sestofts glimrende »Introduktion til Bourdieus litteraturanalyse», $K \& K 79$ (1995). 
som et medierende niveau mellem den socio-politiske virkelighed og den litterære tekst. Det er dette (kryds)felt mellem eksterne og interne forhold, der udgør værkets primære kontekst, og det er her, den institutionelle tilgangs to undersøgelsesområder vokser sammen: på den ene side det, der produceres (værket betragtet som autonomt æstetisk objekt: tematiske, stilistiske, genre- og udsigelsesmæssige valg), og på den anden side det, der producerer (den litterære praksis forstået som forfatterens positionering og status i en given konfiguration; tid og sted for skriveprocessen).

Den institutionelle tilgang kan herefter kort beskrives som en historiserende tekstlæsning, der inddrager værkets produktions- og receptionsbetingelser som kontekstuelle faktorer. ${ }^{14}$ Det er for de frankofone studier derfor ikke uvæsentligt, at den franske litteraturkritik fortsat overvejende fungerer ud fra forestillingen om fransk sprog, litteratur og identitet som den centrale norm, alle undersystemerne hver især kan defineres - positivt eller negativt - i forhold til. ${ }^{15}$

En sammenligning af to romaner fra henholdsvis Belgien og Québec kan eksemplificere, hvordan dette samspil mellem, sprog, identitet og (litteratur)system helt konkret har udmøntet sig i to forskellige litterære bevægelser. Jeg starter med belgitude-bevægelsen, som udgør et oplagt udgangspunkt for konstruktionen af et sammenligningsgrundlag.

\section{På den ene side af Atlanten: Belgien}

Siden statsdannelsen i 1830 har Belgien som bekendt ændret sig fra en fransksproget enhedsstat til en flersproget føderal stat, hvor to store sprogsamfund - nederlandsktalende flamlændere og fransksprogede ${ }^{16}-$ står stejlt over for hinanden, mens et lille tysksproget mindretal ser til fra sidelinjen.

14. Jeg refererer her til flere teoretikere, der har forsøgt at formulere de principper for den litterære analyse, der helt klart mangler hos Bourdieu. Jacques Dubois: L'Institution de la littérature. Introduction à une sociologie, Paris-Bruxelles 1986. Dominique Maingueneau: Le Contexte de l'œuvre littéraire. Énonciation, écrivain, sociéte, Paris 1993. Alain Viala: "Sociopoétique« in Georges Molinié et.al.: Approches de la réception : sémiostylistique et sociopoétique de Le Clézio, Paris 1993.

15. Se f.eks. Pierre Piret: „Une francophonie multilatérale ?«, in Pierre Halen et al. (ed.): Littératures belges de langue française. Histoire et perspectives 1830-2000, Bruxelles 2000.

16. En vis terminologiforvirring præger fremstillingerne af, hvilke sprog der tales af hvem i Belgien. Flandern og Wallonien er betegnelser for geografiske og administrative enheder, men sprogligt er såvel flamsk som wallonsk betegnelse for dialekter. Nederlandsk er Flanderns officielle sprog, mens der tales fransk i Wallonien. Bruxelles-regionen er som den eneste officielt tosproget men i realiteten næsten $90 \%$ fransktalende. 
Hvis man tidsfæster Belgiens fransksprogede litteratur til at starte med statsdannelsen i 1830, dækker den end ikke to århundreder. Ikke desto mindre er der skrevet et overvældende antal belgiske litteraturhistorier, snart om la littérature française de Belgique, snart om la littérature belge de langue française, og der er mere end en sproglig nuance til forskel. Det er selve spørgsmålet om nationsbegrebets ontologiske status, der er på spil.

I det 19. århundredes Belgien dominerer en nationalistisk ideologi såvel politisk som litterært, men i takt med skærpelsen af konflikten mellem nationale og regionale interesser, indtages den litterære institution fra omkring 1920 af en assimilerende holdning, der har fået sit mest koncentrerede udtryk i det såkaldte Mandagsmanifest fra 1937:

"Ikke blot har sprogfællesskabet mellem vores franske litteratur og franskmændenes litteratur skabt en lighed, der er meget vigtigere end de uligheder, der udspringer af den fysiske og politiske geografi. Men de historiske tilfældigheder, naboskabet, de åndelige forbindelser, den franske kulturs uovertrufne universalitet og tiltrækningskraft har reduceret de følelsesmæssige nuancer mellem de to landes litteratur til et minimum. $\ll^{17}$

Efter den gloriøse periode hvor den belgiske litteratur konstituerede sig som national og hævdede sin forskel fra den franske litteratur, er altså fulgt et halvt århundrede domineret af sproglig determinisme og negeringer af det nationale. I 1970'erne svinger det litterære pendul tilbage mod en distinktionslogik.

Det ny kapitel i den litteraturhistoriske udvikling kan ses som et sammenfald af flere såvel eksterne som interne omstændigheder af helt forskellig karakter. I løbet af 1970'erne begynder den franske litteratur at miste lidt af den aura, efterkrigstidens skiftende litterære og teoretiske strømninger havde omgivet den med. Eksistentialismen, feminismen og le nouveau roman har udspillet deres rolle, og selv om den strukturalistiske bølge stadig giver dønninger, fremstår den franske hovedstad ikke længere som det uantastede centrum for al fornyelse. Desuden har afkoloniseringen sat fokus på en række fransksprogede tekster, der med ofte spændende litterære kombinationer af traditionelle europæiske former og mundtlige fortælletraditioner åbner døren til hidtil ukendte universer. Endelig - på et noget andet plan men med klar indflydelse på den litteraturhistoriske debat - underkastes nationstænkningen en kritisk analyse, hvorefter nationalstaten mindre og

17. Manifeste du Groupe du lundi, Bruxelles, ler mars 1937. 
mindre fremstår som en uproblematisk størrelse, men mere og mere som en moderne konstruktion.

Indadtil sker der med føderaliseringen af den belgiske stat nogle gennemgribende sociopolitiske forandringer, som tvinger de fransktalende belgiere til at reflektere over de bestanddele, der udgør deres nationale og kulturelle selvforståelse. Reduktionen af den belgiske enhedsstat til en næsten tom ramme og dermed til en ugyldig reference sætter litteraturen fri af den ørkesløse debat for eller imod eksistensen af noget essentielt belgisk. En ny generation af belgiske intellektuelle påpeger, at talen om belgisk litteratur blot anerkender eksistensen af et litterært korpus skrevet i en litterær konfiguration, der er indlejret i det belgiske samfund. I 1970'erne er dette samfund i opbrud, og det er på den baggrund, man kan forstå belgitudebevægelsen, der lanceres i det franske litterære tidsskrift Les Nouvelles littéraires i $1976 .^{18}$

Tillægget, der præsenterer belgitude-begrebet, bærer titlen Et andet Belgien og giver ordet ikke blot til yngre forfattere men også til sociologer, musikere, malere og filminstruktører. Lynhurtigt annekteres begrebet dog af de litterære kredse. I centrum af bevægelsen placeres nemlig ikke kun forholdet til et sønderrevet Belgien, men i lige så høj grad de sprog- og identitetsproblemer, der bunder i forholdet til Frankrig som kulturel overmagt. Et problemkompleks der tilsyneladende ikke i samme omfang berører de andre kunstarter.

I den indledende artikel fremsætter tillæggets ansvarshavende, forfatteren Pierre Mertens, en reel krigserklæring mod det assimileringsparate establishment, der skrev og promoverede formelt yderst konventionel litteratur, der på det referentielle plan holdt sig på solid afstand af den sociale og (især) nationale virkelighed. Belgitude-begrebet indleder dermed en intern belgisk fejde om litteraturens form og funktion, idet Pierre Mertens holder forfatteren ansvarlig for, at der bliver udvekslet billeder af det fælles liv og hævder, at assimileringsstrategiens systematiske undertrykkelse af belgisk relaterede temaer har haft vidtrækkende konsekvenser for konstruktionen af den sokkel, de fransktalende belgieres selvforståelse kunne hvile på.

Bevægelsen rummer en både litterær og samfundsorienteret dimension, der gør den egnet til såvel intern som ekstern brug: internt muliggør bevægelsen som nævnt en gruppe yngre forfatteres positionering på det litterære felt med et projekt, der dels sigter mod en fornyelse af det litterære formsprog, dels søger at udnytte litteraturens identitetsskabende potentiale;

18. Pierre Mertens (ed): "Dossier : Une autre Belgique«, in Les Nouvelles Littéraires 2557 (1976) (herefter forkortet $» \mathrm{D} \ll$ ). 
eksternt retter den sig mod den parisiske litterære institution i et forsøg på at formulere andre præmisser for det belgiske særpræg end de hidtil gældende, der i den givne politiske kontekst fremstår som alt for nationalt funderet.

Belgitude-begrebet er selvfølgelig inspireret af négritude-begrebet, der blev lanceret af martinikaneren Aimé Césaire sidst i 1930’erne og særlig blev udnyttet af Senghor i bestræbelserne på positivt at valorisere den 'sorte sjæl'. Det kan virke provokerende, at et lille vestligt land overtager et udtryk, der konnoterer ikke bare symbolsk dominans, men også politisk undertrykkelse, og begrebet problematiserer da også overvejende den symbolske dimension, der ovenfor er defineret som fælles for alle de frankofone litteraturer. Den turbulente indenrigspolitiske situation i Belgien gør det imidlertid muligt at tillempe begreber og problemstillinger fra de nye postkoloniale litteraturer, som nu er genstand for nysgerrig interesse i Frankrig.

Da fortællingen om den belgiske nations oprindelse helt åbenlyst fremstår som et utroværdigt konstrukt, foretager de fransktalende belgiere en manøvre, der ganske som négritude-bevægelsen, konverterer de i den receptionsæstetiske diskurs negativt valoriserede værdier til positive; vist er den belgiske historie kort og kaotisk og blottet for virkelige oprindelsesmyter, men netop derfor er den ikke tyngende og forpligtende som den franske:

"Hvornår lærer vi dog at anse vores status som bastarder, som forældreløse, som et privilegium? (...) Hvornår opdager vi, hvilken lykke det er ikke at skylde nogen kultur noget og at befinde sig dér hvor alle påvirkninger mødes? (...) Vi burde efterhånden forsøge at være belgiere. Marginale måske, i undertal helt sikkert og lige så sikkert i eksil, men uden at flytte os ud ad stedet«(»D«, p. 14).

Med erklæringen om, at »den bedste måde at være universel på er at acceptere sin indfødthed«(»D», p. 14), indikeres, at det at være fransksproget belgisk forfatter ikke længere betyder, at man for enhver pris skal differentiere sig ved at skrive 'nationalt', men at man omvendt heller ikke bliver universel ved blindt at fraskrive sig enhver lokal forankring. Belgitude-projektet må derfor tilstræbe en særlig form for dialektik mellem det lokale og det globale.

Litteraturens og sprogets identitetsskabende rolle er emner, der optager de belgiske forfattere voldsomt i 1970'erne og det meste af det følgende årti; mange litterære tekster tager fat i en eller anden form for identitetsproblematik. En af de bedste er Jean Munos (1924-1988) veloplagte Histoire exécrable d'un héros brabançon (En skrækkelig historie om en helt fra Brabant) fra $1982 .^{19}$ 
Romanen, der er en selvbiografisk roman - en autofiction - indledes med en prolog, hvor jeg-fortælleren Papin sidder og ser det franske litteraturmagasin Apostrophes i fjernsynet. Studieværten har inviteret forfattere fra forskellige franske regioner i studiet, for at de skal berette om deres rødder. En efter en genkalder de sig barndommens idylliske univers, men forfatteren fra Alsace sidder fortabt tilbage og må forklare, at historien har leget kispus med hans rødder... Denne indledende rundtur i den franske identitet lancerer temaet om den kollektive identitet, der fås i to udgaver: en hel og fuld identitet hos (de fleste af) franskmændene og så en tvivlsom vanskelig definerbar identitet, som den fransksprogede belgiske fortæller genkender sig selvi.

»Hvem er du? Hvem er du? Hvem er du?«(HIST, p.16) udfordres fortælleren af en fugl, der har slået lejr i hans dagligstue. Og umuligheden af at formulere et klart svar på dette spørgsmål hensætter ham i en tilstand af dyb melankoli grænsende til angst. Med denne eksistentielle tvivl, som altså motiveres med en udsendelse om fransk litteratur, åbnes for et tilbageblik på en livslang identitetssøgen - social, national og kulturel - der kulminerer i 1980’ernes splittede Belgien.

Fortællerens familie har svært ved at opfatte sig som flamlændere, wallonere eller hovedstadsbeboere - Bruxellois; politisk er familien hverken til højre eller til venstre; religiøst set er de hverken troende eller ateister. Alt i alt er deres identitet sammensat af en forfærdelig masse benægtelser, og denne tematik om den kollektive identitet, der kun lader sig definere negativt, er hele tiden underliggende i romanen, hvad enten det drejer sig om nationaliteten, det noget fantasmatiske forhold til det franske sprog eller litteraturopfattelsen.

Familiens identitet synes primært at være forbundet med deres sociale funktion som lærere og forfattere. Fortællerens forældre definerer sig som intellektuelle og lader Papin forstå, at de som intellektuelle har visse pligter hvoraf én af de fremmeste er at hæge om det franske sprog. I mangel af en nationalitet, man kan være bekendt - den belgiske identitet afvises med et "Lille land - små mennesker«(HIST, p. 70) - spiller det franske sprog en kompensatorisk rolle som redningsplanke for den altid prekære identitet. »Mit sprog, det er mit fædreland«(p. 191), forkynder faderen og gør sig dermed til talsmand for den i miljøet af undervisere og forfattere udbredte assimilerende holdning:

19. Jean Muno: Histoire exécrable d'un héros brabançon, Bruxelles 1998 (org. 1982) (herefter forkortet HIST). 
„På dette område var han [faderen] kategorisk: blandt alle de benægtelser, der definerede os, var der dog i det mindste en bekræftelse, der eftertrykkeligt gjorde sig gældende: vores fædreland, det var vores smukke sprog«(HIST, p. 75).

Papin opdrages altså i en slags kult omkring det franske sprog. Forældrene har under titlerne Sig - Sig ikke og Den enkle og komplette forfattet et par normative værker om det franske sprog. Disse værkers konsekvenser for den enkeltes udtryksmåde demonstreres af Papin, som ufrivilligt har udgjort en væsentlig del af studieobjektet for disse bøger og derfor er blevet meget varsom med at udtrykke sig spontant. Hver eneste af hans fejl er blevet noteret og indlemmet i samlingen af det, man skal undgå at sige, hvis franskmændene ikke skal opdage, at man ikke er fuldstændig fransk. Det er selvfølgelig den puristiske norm, den ekstremt kontrollerede brug af sproget over for den frie variant, der hudflettes her.

Den til underkastelse grænsende respekt for alt, hvad der fransk, fremkalder en af de yderst sjældne manifestationer af selvstændighed, som Papin drister sig til i sin barndom. Første gang, han ledsager forældrene til Paris, bliver han så tirret af faderens lattervækkende forsøg på at agere og især tale mere parisisk end pariserne selv, at han prompte reagerer med et par såkaldte belgicismer, altså specifikt belgiske udtryk. Siden undrer han sig:

»Ja, hvad gik der egentlig af mig? Det kan jeg stadig undre mig over. Ønsket om at være fremmed var sikkert det vigtigste. Måske også en anelse provokation? Foran min Hr. Fader der "parisianiserede» som en fisk i vandet en pludselig trang til at skille mig ud. Det er meget sjovt, for jeg hævdede faktisk min belgitude fyrre år før den blev opfundet... [...] Og samtidig opdagede jeg dette: franskmændene elsker os, når vi fremmedgjorte fremmedgør dem, de elsker os lettere eksotiske, vi der er født på medaljens bagside« (HIST, p. 74).

Med en eksplicit reference til belgitude-bevægelsen konstaterer Papin, at parisernes imødekommenhed er proportional med graden af fremmedhed hos den anden: det kan betale sig at være lidt afvigende! Der er ikke på dette sted i bogen tale om en egentlig litterær problematik, men det er svært ikke at læse citatet som en illustration af den inkorporering af de parisiske litterære instansers afventende blik, som mange frankofone forfattere har forsøgt at frigøre sig fra i det 20. århundredes sidste årtier. I romanen repræsenteres dette blik af den frankofile fader og de kredse, han introducerer sønnen til. 
Romanen giver en ætsende morsom beskrivelse af det officielle litterære miljø, hvor man "plejer den skrøbelige lille litteratur« (HIST, pp. 79-80), der har behov for permanent kunstigt åndedræt. Dog understreges det, at denne ynkværdige litteratur er meget tapper, fordi den takket være de officielle poeters klubs solide bolværk mod udefrakommende strømninger - både i betydningen nye litterære tendenser og social virkelighed - forbliver ren og skær i et århundrede, hvor alt andet er til fals:

»En ting var de enige om: den lille litteratur skulle forblive ulykkelig, ren i sine pjalter. Jomfru og martyr, kun sådan kunne man elske den, dér var hele dens charme. I skulle se dens glæde når den fik en lille kjole fra Paris eller, ved juletid, lidt Goncourt-sovs med appelsinsmag. Det var en glæde, der så rigeligt kompenserede for al ens opofrelse« (HIST, pp. 263264).

Den institutionelle tematik er her helt gennemsigtig. Ikke overraskende at Papins litterære skabertrang - som med et velkendt modernistisk fortælleteknisk greb bliver til den roman, vi sidder og læser - først realiseres efter faderens død og den dermed muliggjorte afstandtagen til det officielle litterære miljø.

Efterhånden som den nationale virkelighed bliver dobbelt, begynder forfatternavnet Muno mere og mere at optræde som Papins alter ego, og i fortællingens sidste del veksler fortælleinstansen hele tiden mellem den kendte jeg-fortæller og en implicit fortællestemme, der omtaler Papin i tredje person. Udsigelsesniveauet spaltes i takt med landets opdeling og således iscenesættes - her også sprogligt - den dobbelthed og splittethed, der nu fremstår som den fransksprogede belgiers grundlæggende eksistensvilkår:

"Alene det at gå ned ad min avenue/laan om morgenen. Da sproggrænsen går lige igennem vejen, havde jeg en fod i Flandern og en anden i Wallonien. Det samme med hjernen: en halvdel til hver side. Det samme med armene, benene, alt det man har to af. Men hvad med hjertet, som sidder til venstre? Når alt kommer til alt, siger jeg til mig selv, er det snart wallonsk, på den fædrene side, snart flamsk, mijn hart, på Moeder Liza's side. [...] Snart slås mine to halvdele, snart har den ene overtaget, snart den anden. Det sker også at de kommer med indrømmelser. Ah! Kompromis'et.. Så er det at jeg føler mig allermest belgisk, og paradoksalt nok, mest uautentisk, mest marginal. Både indenfor og udenfor, som en af de andre og alligevel en anden«(HIST, pp. 343-344). 
Føderaliseringen har marginaliseret den nationale belgiske identitet i forhold til de regionale, gjort flamlændere og wallonere til fremmede for hinanden. Det er imidlertid slående, at selv om forholdet til flamlænderne og det nederlandske sprog tematiseres, så er fortællerens selvforståelse i langt højere grad beroende på referencen til Frankrig: i indledningen funderer den splittede helt over sin identitet foran en udsendelse om fransk litteratur; det er i Paris, han opdager sin belgitude, og tilhørsforholdet indkredses såvel geografisk, historisk, politisk som litterært - systematisk med Frankrig som modbillede: stort historieskabende land $v$ s lille land skabt af historiske tilfældigheder; konsolideret nation indskrevet i kontinuiteten vs kollapset nation markeret af stadige brud; stærk identitet $v s$ negativ identitet; prestigiøs litterær arv $v s$ litterær tradition under stadig rekonstruktion.

Den af Pierre Mertens efterspurgte dialektik mellem det lokale og det globale medieres altså langt overvejende med det franske centrum som omdrejningspunkt. En sådan mekanisme kan - i lyset af denne artikels indledende overvejelser - hævdes at illustrere den litterære frankofonis fællesvilkår, idet den genfindes i andre bevægelser og hos andre forfattere, der befinder sig på strukturelt sammenlignelige positioner i systemets underfelter.

Belgitude-bevægelsen er i mange henseender en pendant til den identitetsbevægelse, der opstod i den canadiske Québec-provins i 1960'erne. Også her opstod bevægelsen synkront med en omkalfatring af interne samfundsstrukturer, men er med tydelige diskursive reminiscenser fra afkoloniseringens store tænkere også påvirket af eksterne forhold. Vi genfinder debatten om litteraturens identitetsskabende rolle og et udpræget generationelt aspekt, hvor yngre intellektuelle løber storm på et kulturelt establishment. Endelig tegnes bevægelsen som i Belgien overvejende af forfattere, der udgives - eller forsøger at blive udgivet - i Frankrig.

\section{På den anden side af Atlanten: Québec}

Det vil være nyttigt indledende kort at erindre om den canadiske delstats omskiftelige historie, siden den franske opdagelsesrejsende Jacques Cartier banede vejen for grundlæggelsen af en fransk koloni i 1600-tallet. I 1763 kom området på britiske hænder og indgår sammen med resten af Canada i et rigsfællesskab med Storbritannien frem til 1931. Historien har efterladt en fransk kultur, der ikke som på kontinentet udvikler sig i takt med revolutionære og verdslige idealer, men som tværtimod - som værn mod den engelske tilstedeværelse - med næb og kløer klyngede sig til katolicismen som overordnet samfundsideologi. 
Indtil 1960'erne var Québec gennemsyret af den katolske kirkes indflydelse, hvad den litterære produktions overvægt af præsteforfattere og hjemstavnsromaner bærer tydeligt præg af. Men i kølvandet på Den Stille revolution - La Révolution tranquille - der i 1960 bringer de liberale til regeringsmagten, fejer en ideologisk vind af stormstyrke hen over provinsen og efterlader et samfund markeret af reformer og løsrivelsesbevægelser med krav om øget selvstyre og styrkelse af fransk i forhold til engelsk.

Med reformerne følger en næsten eksplosiv løsrivelse af litteraturen, der indtil da illustrerede de to former for afhængighed - kulturel og politisk (heteronomi) - der i varierende omfang karakteriserer alle de frankofone litteraturer. Benævnelsen litteratur fra Québec på bekostning af fransksproget canadisk litteratur synliggør viljen til at nationalisere litteraturen både formelt og institutionelt. I toneangivende litterære kredse cirkulerer en idé om den "nationale tekst», der dækker over en temmelig voluntaristisk indstilling til skabelsesprocessen:

"Hvad enhver ung forfatter fra Québec burde vide er, at han ikke kan unddrage sig det pres, Provinsen udøver, for han vil opdage, når han har mistet sin uskyld, at det ikke er ham, der skriver sine bøger (dem han signerer med sit navn), og at der i Quebec kun er en eneste Forfatter : OS ALLE [...]. En forfatter kan ikke forsøge at eksistere uden for den quebecske tekst, han er nødt til at deltage i det kollektive projekt, ellers er det intetheden. $\ll^{20}$

Litteraturkritikken er ikke sen til at suspendere det æstetiske aspekt og læse værkerne som fragmenter af den kollektive "nationale tekst«. Mange forfattere ser et formelt brud med det franske litterære sprog som en forudsætning for fremskrivningen af en quebecsk originalitet. Denne søgen efter et autentisk sprog bliver helt central i bevægelsen og fører til et forsvar for en litterær anvendelse af den lokale dialekt joual. ${ }^{21}$ Der er langt fra konsensus om dialektens litterære kvaliteter, men de forfattere, der tager udfordringen op, revolutionerer det litterære sprog så grundlæggende, at joual en overgang fremstår som det mest åbenlyse symbol på en quebecsk specificitet.

20. Citeret i Jean-Marie Klinkenberg: Une étude de 'Salut Galarneau' de Jacques Godbout, Montréal 1997.

21. De frankofone litteraturer frembyder andre eksempler på litterære bevægelser, der anvender en folkelig sprogbrug som argument for en specifik litterær identitet. C.F. Ramuz skriver i 1914 et glødende forsvar for en litterær anerkendelse af vaudois, en schweizisk dialekt. I 1989 udgiver J. Bernabé, P. Chamoiseau og R. Confiant en Hyldest til kreoliteten, der gør brugen af kreolsk til præmis for konstruktionen af en specifik litteratur. Se f.eks. Pascale Casanova: La République mondiale des lettres, Paris 1999. 
Jacques Godbouts roman Salut Galarneau! fra 1967 er en af de tekster, der har båret ved til det kollektive projekt. ${ }^{22}$ Romanen har i dag status af moderne klassiker men var allerede ved udgivelsen en dundrende succes, ikke mindst fordi den altovervejende blev læst som en allegori over Quebecs historie.

Salut Galarneau! fremstår som François Galarneaus dagbog. Fortælleren har kompromitteret sit brændende ønske om at blive etnograf ved at forlade skolen i utide og ernærer sig nu som pølsemand for lokalsamfundet og amerikanske turister. På opfordring fra broderen Jacques og kæresten Marise begynder François så småt at skrive, og da kæresten dropper ham til fordel for Jacques lader Francois sig mure inde med sit manuskript, indtil han erkender, at skabelsesprocessen i hans tilfælde næres af virkelighedskontakt. På romanens sidste sider forcerer han muren til sit selvvalgte eksil for at »bringe [s]in bog ind til byen så Jacques og Arthur, Marise, bedstefader Aldéric, mor, Luis og... alle svigerfamilier i hele verden læser den« ( $S G, \mathrm{p}$. 158).

Den anglo-amerikanske påvirkning og den katolske kirkes hegemoni løber gennem romanen som to sider af den samme historie og indskrives på flere planer: tematisk, stilistisk og på personniveau. Den ældste bror, Arthur, er tilknyttet præsteseminariet, den mellemste broder Jacques fører en american way of life ved at producere reklametekster og manuskripter til tv-serier, mens den sidst tilkomne, François, er selve sindbilledet på den gennemsnitlige Quebec-borger: „Sociologerne har konsulteret deres statistikker og fundet den gennemsnitsborger, de kan anbefale, man laver test med: François Galarneau, mand af sin tid $[\ldots] \lll(S G$, p. 76$)$.

Romanens projekt handler derfor mindre om at gen- eller opfinde en quebecsk identitet - Galarneau er denne identitet - end at skabe betingelserne for, at denne identitet kan udfolde sig, idet fortælleren endnu ikke har »fordøjet hverken englænderne eller præsterne« (SG, pp. 73-74), hvis tilstedeværelse fortsat hviler tungt over samfundet blandt andet i form af repræsentationer, hvis indflydelse til stadighed bringes i erindring af det sproglige og sociale hierarki. Det forklarer Galarneaus foragt for ejeren af Henault's Drugstore:

„Han kunne da have kaldt det Pharmacie Hénault, for pokker, men han er så glad for at han kan tale engelsk, at hvis hans kone siger je t'aime i stedet for I love you, kan han ikke få den op at stå. Koloniseret er han, Hénault : en testikel malet i Union Jack's farver, den anden med Pavens våbenskold«(SG, p. 59).

22. Jacques Godbout: Salut Galarneau?, Paris 1995 (org. 1967) (herefter forkortet $S G$ ). 
Denne anglofili får sin modsætning hos Onkel Léon, konservator(!) af profession, som har foreslået François at erststatte hot dog med det franske chien chaud:

"[Onkel Léon] viser samme ærbødighed for det franske sprog som en Kirkens mand. Han er purist: for ham er fransk en opera, og han tåler ikke, der bliver sunget falsk. Han er en værre en, ham Léon. Grammatikken, det er Gudfader og USAs præsident på samme tid. Og derfor ville han have, at jeg kaldte min pølsevogn Au roi du chien chaud. Kan I se det for jer?«(SG, p. 33).

Fortælleren er afgjort ikke purist. Romanen er isprængt engelsk-amerikanske ord og vendinger samt $\mathrm{i}$ et enkelt tilfælde en hel dialog på engelsk. Til eksempel et uddrag fra romanens indledning (de kursiverede ord optræder på engelsk i originalteksten):

»I dag er der især amerikanere på ferie, de kommer for at besøge den smukke provins, forskelligheden, gæstfriheden spoken here, de kommer via Ontario: jeg er sikkert deres første Québec-indbygger, deres første native« $(S G$, p. 13).

Faktisk afspejler teksten på positiv vis det permanente sprogmøde mellem fransk og engelsk og slår først om til kritik, når brugen af engelsk nærmer sig sprogimperialisme som hos ejeren af Hénault's Drugstore. Ironisk nok er sprogets identitetsskabende funktion - i litterær sammenhæng - tæt forbundet med tilstedeværelsen af et anglo-amerikansk islæt, der kan tekstliggøre en quebecsk specificitet i opposition til den franske litterære norm.

Tematiseringen af sprogbrugen udgør et af de tematiske sammenfald med Munos roman. I den belgiske roman blev det sproglige overjeg inkarneret af faderen, mens det her er storebroderen Jacques, som har studeret i Paris og mestrer de franske litterære normer, der lover at korrigere grammatik, ortografi og adjektiver. Ligeledes er Jacques leveringsdygtig i kanoniske litterære modeller :

»Jacques kommer hver gang med en bog, jeg skal læse. Jeg kunne simpelthen ikke komme igennem den sidste. André Gides dagbog. En underlig fyr der som en anden frygtsom gammeljomfru skriver sætninger med hængsler for at kunne analysere sine følelser: en masse som og der lænket sammen som ænder i et skydetelt« $(S G$, p. 83). 
På samme måde som der sprogligt navigeres mellem fransk og engelsk, krydser fortælleren rundt i farvandet mellem divergerende litteraturopfattelser for at finde sit eget ståsted. Der er altså - som i Munos roman - en utvetydig fiktionalisering af det litterære mulighedsrums poler: Gides farveløse dagbogsskriverier illustrerer Galarneaus repræsentation af den franske litteratur som introspektion afskåret fra historien og samfundet. Modellen forkastes, ganske som det sker med den mere kommercielle pol tegnet af Jacques, som formedelst ussel mammon skriver for både englændere og magtens mænd ( $S G$, p. 87). Galarneau finder sin plads, da han under sin frivillige indemuring - en slags elfenbenstårn af beton - arbejder på sin bog:

»[...] Og så, ja, hvis jeg skal være ærlig, så keder jeg mig ad helvede til, det er lige før jeg begynder at spille kunde [i pølsevognen], at jeg bestiller noget at spise, jeg har brug for møder, for blomster, for mennesker, det er bedre at blive bedraget end at være isoleret, jeg har lyst til at tale, til at omfavne, at trykke hænder, at spille kort, at lyve for nogen... [...] Jeg ved godt, at de to ting ikke kan lade sig gøre på samme tid: enten lever du, eller også skriver du. Men jeg vil skrileve« (SG, pp. 156-157).

Galarneaus afsondrethed lammer hans pen og gør ham det klart, at hans skriveri kun får mening i kontakten med omverdenen. Romanen gestalter således en fortæller, der fremstår som en mand af folket, en gennemsnitlig og dermed repræsentativ Québécois, som - ikke mindst takket være pølsevognsklientellet - har privilegeret adgang til folkeånden. Hermed har han legitimeret sig selv som en slags folkets pennefører... og som ganske mange andre frankofone forfattere bragt mindelser frem om den romantiske opfattelse af forfatteren som privilegeret medium for nationalånd (og -sprog!).

Det er værd at minde om, at romanen blev udgivet på det parisiske forlag Seuil, hvorfor den ikke blot indgår i et lokalt, men også i et mere omfattende frankofont kredsløb. Det synes den oplagte 'nationale' læsning ikke altid at tage højde for, og man kan med en vis berettigelse spørge, om en så 'etnificeret' fiktion ikke i lige så høj grad henvender sig til læsere uden for som inden for det samfund, der repræsenteres. Her er det, sammenligningen med Muno bliver interessant. ${ }^{23}$

23. Pierre Halen har sammenlignet de to romaners iscenesættelse af den franske litterære institution med en antillisk roman i »Une belligérance française. Images conflictuelles du centre dans le roman francophone contemporain (Godbout, Muno, Confiant) «, in Jean-Pierre Bertrand et.al. (ed): Littératures mineures en langue majeure. Québec/Wallonie-Bruxelles, Montréal-Bruxelles 2003. 


\section{Sammenligning og perspektivering}

Der er, som det vil være fremgået af de historiske opsummeringer, væsentlige forskelle mellem de to forfatteres udgangspunkt: den belgiske bevægelse opstår som en defensiv reaktion på flamlændernes krav om øget kulturelt og økonomisk selvstyre inden for nationens rammer, hvorimod den quebecske udgave faktisk er sammenlignelig med den flamske og kan karakteriseres som offensiv, præget af optimisme og en positiv selvforståelse.

Ikke desto mindre er der evidente tematiske sammenfald og tydelige stilistiske lighedspunkter, ligesom både dagbogs-romanen og den selvbiografiske roman udnytter muligheden for at bringe fortællingens mekanismer til skue. Og hvad der er nok så interessant: i begge tilfælde etableres en udsigelsessituation, der placerer fortælleren i et udkantsområde - Papin skriver fra en forstad til Bruxelles, mens Galarneau holder til i en vejkant uden for byen. Disse romaner er stemmer fra periferien!

En institutionel læsning vil nu hævde, at udsigelsesforholdene er en iscenesættelse af den symbolske dominans, begge forfattere er fanget $i$, og at romanernes forkastelse af de franske litterære modeller er en afvisning af assimileringsstrategien. Tilbage bliver en differentieringsstrategi, som romanernes metafiktionelle dimension opfordrer til at læse som et helt bevidst spil med det litterære centrums forventningshorisont. Teksterne udstiller anderledesheden med alle til rådighed værende ressourcer heriblandt indskrivningen af den flersprogede virkelighed i form af nederlandske og engelske ord.

Selv om flamlændere og englændere er vigtige elementer i romanerne, er det imidlertid ikke disse befolkningsgrupper, der gør det muligt for fortællerne at formulere et svar på spørgsmålet: hvem er jeg? Dette svar bygger langt overvejende på en opposition til den franske reference.

Det er selvfølgelig ikke nyt, at modsætningsstrukturen er et vilkår for identitetstænkningen, men det er unægtelig interessant, at den modpol, der i langt overvejende grand synes at nære selvforståelsen i disse to romaner fra hver sin side af Atlanten er ... Frankrig. I begge romaner væves overvejelserne over en kollektiv identitet sammen med litterært relaterede problemstillinger. Derfor rejser disse tekster nogle helt principielle metodiske spørgsmål om, hvorvidt det er muligt for en forfatter at adskille sin refleksion over begreber som kollektiv identitet fra sine overvejelser over den litterære identitet, altså hvorvidt der metodisk er belæg for at se eksempelvis Jean Munos identitetsfremstilling som repræsentativ for de fransksprogede belgiere.

En anerkendelse af forfatterens mere eller mindre implicitte fordring på at repræsentere samfundets identitet afhænger selvsagt af den måde, forhol- 
det mellem litterær tekst og samfundsproblematik tænkes på. De to romaner har klart vist, at Muno og Godbouts bud på en kollektiv identitet er filtreret gennem det frankofone litterære systems prisme. Det betyder ikke, at teksterne ikke kan tage stilling i de konflikter og debatter, der ligger uden for dem, eller at de ikke kan række langt ud over den specifikt litterære sfære. Men det betyder, at tekster som disse, der afgjort siger meget om, hvad det vil sige at være fransktalende belgier og canadier i et samfund på jagt efter en særegen identitet, siger mindst lige så meget om, hvordan den frankofone forfatter kommer til skriften.

Er det da så vigtigt, hvis romanerne er gode og finder vej til sine læsere? $\mathrm{Ja}$, når det drejer sig om at vurdere de forskellige tilganges muligheder og begrænsninger i de frankofone litterære studier, hvor sprog- og identitetsproblematikken står så centralt.

Den institutionelle tilgang objektiverer de relationer, der - som svar på artiklens indledende overvejelser - udgør det sandsynligvis eneste plan, hvor de frankofone litteraturer er sammenlignelige i al deres forskellighed: nemlig relationerne til det franske litterære centrum, der griber langt ind i hver enkelt af disse litteraturers skabelsesbetingelser og udgivelsesstrategier. For nogle forfattere så langt, at sprog- og identitetsproblematikken kontinuerligt medieres via Paris, det uomgængelige omdrejningspunkt for deres søgen efter (litterær) legitimitet. Det er de forfattere, der udgør det frankofone litterære system og berettiger et komparativt arbejde.

Hermed afvises muligheden for at lægge en global teori ned over det samlede genstandsfelt, som Mouras læsning prætenderer. Og hermed relativiseres en alt for mekanisk opfattelse af den frankofone forfatter som repræsentant for et nationalt, regionalt eller etnisk særpræg. En ureflekteret accept af eksempelvis Jean Munos roman som repræsentativ for det fransktalende Belgien slører den omstændighed, at hans udlægning af begreber som litteratur, identitet og sprog finder ekko hos forfattere der befinder sig på en strukturelt sammenlignelig position på den anden side af Atlanten, mens de er genstand for konkurrerende opfattelser i det hjemlige litterære felt, hvor det langt fra er alle forfatterpositioner, der som belgitude-tilhængerne tildeler litteraturen en identitetsskabende forpligtelse. Et komparativt arbejde med det frankofone litterære system fordrer derfor også et grundigt og nuanceret kendskab til de enkelte litteraturers særlige historie.

Således anes konturerne af et omfattende genstandsfelt, der ud over en lang række fascinerende litterære værker, byder på masser af uudforskede sammenhænge at undersøge og metodiske principper at overveje. Faktorer der uophørligt tvinger os til at reflektere over relevansen af de litteraturhistoriske begreber, nationalfilologien har overleveret os - og måske rummer perspektiver for en mere globaliseret komparativ litteraturhistorie? 
